\title{
Four New Limonoids from the Barks of Toona ciliata
}

\author{
Pan-Pan Zhang ${ }^{1} \cdot$ Yun-Ge Bu ${ }^{1}$. Shang Xue ${ }^{1} \cdot$ Zhi-Rong Cui $^{1} \cdot$ Peng-Fei Tang ${ }^{1} \cdot$ Jun Luo ${ }^{1} \cdot$ Ling-Yi Kong $^{1}$
}

Received: 21 August 2020 / Accepted: 12 October 2020 / Published online: 23 October 2020

(c) The Author(s) 2020

\begin{abstract}
Four new limonoids, toonayunnanaes F-I (1-4), and six known compounds $(\mathbf{5}-\mathbf{1 0})$ were isolated from the barks of Toona ciliata. Their structures were elucidated by thoroughly analyzing of NMR and HRMS data, and single-crystal X-ray diffraction of $\mathbf{1}$. The oxetane ring moiety in $\mathbf{1}$ was rare in limonoids and other natural products. Compound $\mathbf{1}$ showed nitric oxide (NO) inhibitory effect with an $\mathrm{IC}_{50} 38.45 \pm 0.41 \mu \mathrm{M}$ in lipopolysaccharide (LPS)-activated RAW 264.7 macrophages.
\end{abstract}

\section{Graphic Abstract}

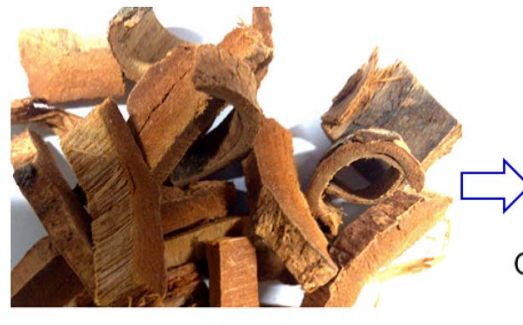

Toona ciliata Roem.

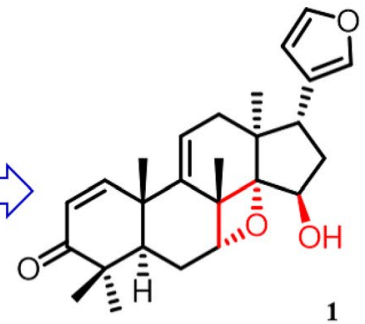

NO inhibitory effect $\left(\mathrm{IC}_{50} 38.45 \pm 0.41 \mu \mathrm{M}\right)$

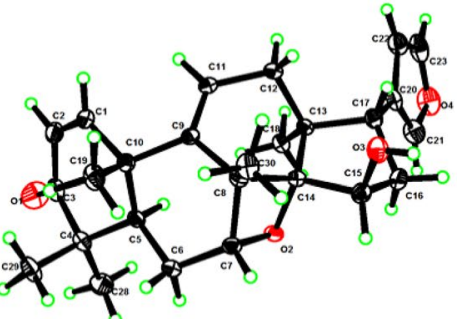

Keywords Meliaceae $\cdot$ Toona ciliate $\cdot$ Limonoids $\cdot$ NO inhibitory effects

\section{Introduction}

In memory of Professor Jun Zhou.

Pan-Pan Zhang and Yun-Ge Bu have contributed equally to this work.

Electronic supplementary material The online version of this article (https://doi.org/10.1007/s13659-020-00274-w) contains supplementary material, which is available to authorized users.

Jun Luo

luojun@cpu.edu.cn

$\triangle$ Ling-Yi Kong cpu_lykong@126.com

1 State Key Laboratory of Natural Medicines and Jiangsu Key Laboratory of Bioactive Natural Product Research, School of Traditional Chinese Pharmacy, China Pharmaceutical University, Nanjing 210009, People's Republic of China
The genus Toona, belonging to the family Meliaceae, contains 15 species mainly distributed in the regions of tropical Asia and Africa, of which four species and six varieties grow in China [1]. Toona ciliata Roem. var. ciliata is a timber tree mainly found in the south of China, such as Yunnan, Sichuan, Guangdong, and Hainan provinces [2]. Its bark has been used in Chinese folk medicine to treat dysentery, fever, and menstrual disorders [3]. Our previous phytochemical investigations on $T$. ciliata var. henryi and T. ciliata var. yunnanensis have led to the isolation of a series of limonoids with potential biological activities such as cytotoxicity, anti-inflammatory, and anti-multidrug resistance (MDR) activities [4-8]. As a part of our continuous research for bioactive limonoids from Toona plants, four new limonoids, toonayunnanaes F - I (1-4), and six known compounds $(5-\mathbf{1 0})$ were isolated from the barks of T. ciliata. Their structures were elucidated by thoroughly analyzing of NMR and 
HRMS data, and single-crystal X-ray diffraction of 1 . The oxetane ring moiety in $\mathbf{1}$ was rare in limonoids and other natural products. Herein, we describe the isolation and structural elucidation of these limonoids as well as their inhibitory effects on NO production in LPS-induced RAW264.7 cells.

\section{Results and Discussion}

Toonayunnanae F (1), colorless crystals, possessed a molecular formula of $\mathrm{C}_{26} \mathrm{H}_{32} \mathrm{O}_{4}$ according to the HRESIMS ion at $m / z$ 409.2376 [M+ H $]^{+}$(calcd. 409.2373). The ${ }^{1} \mathrm{H}$ and ${ }^{13} \mathrm{C}$ NMR data of 1 (Table 1) showed characteristic resonances for a $\beta$-substituted furan ring $\left(\delta_{\mathrm{H}} 7.35,7.16,6.20 ; \delta_{\mathrm{C}} 111.2\right.$, $124.7,139.4,142.8)$, an $\alpha, \beta$-unsaturated ketone $\left(\delta_{\mathrm{H}} 7.08 \mathrm{~d}\right.$,

Table $1{ }^{1} \mathrm{H}$ and ${ }^{13} \mathrm{C}$ NMR data of compounds $\mathbf{1}-\mathbf{4}$ in $\mathrm{CDCl}_{3}(\delta$ in ppm, $J$ in $\mathrm{Hz})$

\begin{tabular}{|c|c|c|c|c|c|c|c|c|}
\hline \multirow[t]{2}{*}{ No. } & \multicolumn{2}{|l|}{$1^{\mathrm{a}}$} & \multicolumn{2}{|l|}{$2^{b}$} & \multicolumn{2}{|l|}{$3^{\mathrm{a}}$} & \multicolumn{2}{|l|}{$4^{\mathrm{a}}$} \\
\hline & $\delta_{\mathrm{H}}$ & $\delta_{\mathrm{C}}$ & $\delta_{\mathrm{H}}$ & $\delta_{\mathrm{C}}$ & $\delta_{\mathrm{C}}$ & $\delta_{\mathrm{C}}$ & $\delta_{\mathrm{H}}$ & $\delta_{\mathrm{C}}$ \\
\hline 1 & $7.08 \mathrm{~d}(10.4)$ & 155.0 & $\begin{array}{l}1.90 \mathrm{~m} \\
1.77 \mathrm{~m}\end{array}$ & 39.1 & $8.00 \mathrm{~d}(10.4)$ & 160.6 & $3.98 \mathrm{t}(5.7)$ & 88.0 \\
\hline 2 & $5.98 \mathrm{~d}(10.4)$ & 125.7 & $\begin{array}{l}2.76 \mathrm{~m} \\
2.31 \mathrm{~m}\end{array}$ & 32.9 & $5.84 \mathrm{~d}(10.4)$ & 124.0 & $2.71 \mathrm{~d}(5.7)$ & 42.7 \\
\hline 3 & & 204.3 & & 217.8 & & 204.3 & & 210.1 \\
\hline 4 & & 44.2 & & 46.4 & & 44.3 & $2.59 \mathrm{~m}$ & 41.8 \\
\hline 5 & $2.32 \mathrm{dd}(13.2,4.0)$ & 44.7 & $2.64 \mathrm{~d}(12.1)$ & 46.7 & $2.28 \mathrm{dd}(13.3,2.6)$ & 46.0 & $2.61 \mathrm{~s}$ & 51.2 \\
\hline 6 & $\begin{array}{l}1.90 \mathrm{~m} \\
1.80 \mathrm{~m}\end{array}$ & 26.3 & $5.31 \mathrm{dd}(12.1,2.3)$ & 72.2 & $\begin{array}{l}1.98 \mathrm{~m} \\
1.83 \mathrm{~m}\end{array}$ & 23.9 & $5.93 \mathrm{~s}$ & 71.4 \\
\hline 7 & $4.82 \mathrm{~d}(3.5)$ & 81.5 & 3.90 br s & 72.1 & 5.27 br s & 73.9 & & 170.8 \\
\hline 8 & & 47.1 & & 42.0 & & 42.2 & & 76.2 \\
\hline 9 & & 148.5 & $1.41 \mathrm{~d}(10.4)$ & 48.6 & $2.37 \mathrm{~d}(8.3)$ & 48.8 & $2.90 \mathrm{~d}(12.0)$ & 54.0 \\
\hline 10 & & 41.4 & & 38.3 & & 40.8 & & 48.0 \\
\hline 11 & $5.66 \mathrm{dd}(8.0,4.2)$ & 121.4 & $\begin{array}{l}1.56 \mathrm{td}(13.5,3.1) \\
1.51 \mathrm{~m}\end{array}$ & 17.9 & $4.30 \mathrm{dd}(8.3,6.1)$ & 67.8 & $4.06 \mathrm{dd}(12.0,4.7)$ & 79.3 \\
\hline 12 & $2.08 \mathrm{~m}$ & 36.1 & $\begin{array}{l}1.94 \mathrm{~m} \\
1.21 \mathrm{dd}(13.5,4.9)\end{array}$ & 34.5 & $4.03 \mathrm{~d}(6.1)$ & 77.1 & $4.23 \mathrm{~d}(4.7)$ & 71.5 \\
\hline 13 & & 51.6 & & 42.1 & & 51.4 & & 47.2 \\
\hline 14 & & 96.8 & $2.84 \mathrm{~s}$ & 60.8 & & 157.5 & & 74.2 \\
\hline 15 & 4.62 br s & 77.7 & & 221.2 & 5.49 br s & 121.1 & $3.50 \mathrm{~s}$ & 54.8 \\
\hline 16 & $\begin{array}{l}1.98 \mathrm{~m} \\
1.87 \mathrm{~m}\end{array}$ & 37.9 & $2.50 \mathrm{~d}(10.2)$ & 43.4 & $\begin{array}{l}2.49 \mathrm{dd}(15.2,10.9) \\
2.41 \mathrm{~m}\end{array}$ & 36.3 & $\begin{array}{l}2.32 \mathrm{dd}(13.6,6.6) \\
1.84 \mathrm{dd}(13.6,11.0)\end{array}$ & 31.3 \\
\hline 17 & $3.27 \mathrm{dd}(13.3,5.1)$ & 43.1 & $3.46 \mathrm{t}(10.2)$ & 37.8 & $3.09 \mathrm{dd}(10.9,7.6)$ & 50.3 & $2.80 \mathrm{dd}(11.0,6.6)$ & 41.3 \\
\hline 18 & $0.54 \mathrm{~s}$ & 19.1 & $0.78 \mathrm{~s}$ & 27.7 & $0.99 \mathrm{~s}$ & 14.8 & $1.02 \mathrm{~s}$ & 14.9 \\
\hline 19 & $1.29 \mathrm{~s}$ & 20.9 & $0.84 \mathrm{~s}$ & 18.2 & $1.31 \mathrm{~s}$ & 20.5 & $1.27 \mathrm{~s}$ & 18.1 \\
\hline 20 & & 124.7 & & 122.9 & & 125.3 & & 123.0 \\
\hline 21 & $7.16 \mathrm{~s}$ & 139.4 & $7.26 \mathrm{~s}$ & 140.3 & $7.39 \mathrm{~s}$ & 140.4 & $7.18 \mathrm{~s}$ & 139.5 \\
\hline 22 & $6.20 \mathrm{~s}$ & 111.2 & $6.27 \mathrm{~s}$ & 110.9 & $6.46 \mathrm{~s}$ & 111.7 & $6.38 \mathrm{~s}$ & 110.0 \\
\hline 23 & $7.35 \mathrm{~s}$ & 142.8 & $7.39 \mathrm{~s}$ & 143.0 & $7.40 \mathrm{~s}$ & 143.2 & $7.38 \mathrm{~s}$ & 143.2 \\
\hline 28 & $1.11 \mathrm{~s}$ & 24.8 & $1.24 \mathrm{~s}$ & 31.3 & $1.09 \mathrm{~s}$ & 26.9 & $1.06 \mathrm{~d}(5.8)$ & 13.0 \\
\hline 29 & $1.05 \mathrm{~s}$ & 21.6 & $1.05 \mathrm{~s}$ & 19.6 & $1.08 \mathrm{~s}$ & 21.5 & & \\
\hline 30 & $1.54 \mathrm{~s}$ & 22.3 & $1.14 \mathrm{~s}$ & 17.2 & $1.24 \mathrm{~s}$ & 30.6 & $1.24 \mathrm{~s}$ & 23.0 \\
\hline 6-Oac & & & $2.13 \mathrm{~s}$ & 21.8 & & & $2.20 \mathrm{~s}$ & 21.1 \\
\hline 6-Oac & & & & 169.8 & & & & 170.3 \\
\hline $7-\mathrm{OCH}_{3}$ & & & & & & & $3.72 \mathrm{~s}$ & 52.9 \\
\hline 7-OAc & & & & & $1.98 \mathrm{~s}$ & 21.3 & & \\
\hline 7-OAc & & & & & & 170.2 & & \\
\hline
\end{tabular}

${ }^{\mathrm{a}} 500 \mathrm{MHz}$ for ${ }^{1} \mathrm{H}$ NMR, $125 \mathrm{MHz}$ for ${ }^{13} \mathrm{C}$ NMR

${ }^{\mathrm{b}} 600 \mathrm{MHz}$ for ${ }^{1} \mathrm{H}$ NMR, $150 \mathrm{MHz}$ for ${ }^{13} \mathrm{C}$ NMR 
$\left.J=10.4 \mathrm{~Hz}, 5.98 \mathrm{~d}, J=10.4 \mathrm{~Hz} ; \delta_{\mathrm{C}} 125.7,155.0,204.3\right)$, and five singlet methyl groups $\left(\delta_{\mathrm{H}} 0.54,1.05,1.11,1.29,1.54\right)$. Those observations together with 26 carbon resonances and 11 indices of hydrogen deficiency, suggested that 1 might be a ring-intact limonoid with an $\alpha, \beta$-unsaturated carbonyl moiety in A ring [8-10] (Fig. 1).

The double bond between C-9 and C-11 was confirmed by the correlations of $\mathrm{H}_{3}-19\left(\delta_{\mathrm{H}} 1.29\right)$ and $\mathrm{H}_{3}-30$ to $\mathrm{C}-9\left(\delta_{\mathrm{C}}\right.$ $148.5)$; of $\mathrm{H}-11\left(\delta_{\mathrm{H}} 5.66\right)$ to $\mathrm{C}-12\left(\delta_{\mathrm{C}} 36.1\right)$; and of $\mathrm{H}_{2}-12\left(\delta_{\mathrm{H}}\right.$ $2.08)$ to $\mathrm{C}-9$ and $\mathrm{C}-11\left(\delta_{\mathrm{C}} 121.4\right)$ in the HMBC spectrum. The HMBC correlations (Fig. 2) from H-7 $\left(\delta_{\mathrm{H}} 4.82\right)$ to C-8 $\left(\delta_{\mathrm{C}} 47.1\right)$ and $\mathrm{C}-6\left(\delta_{\mathrm{C}} 26.3\right)$; from $\mathrm{H}_{3}-30\left(\delta_{\mathrm{H}} 1.54\right)$ to C-7 $\left(\delta_{\mathrm{C}}\right.$ $81.5)$ and $\mathrm{C}-14\left(\delta_{\mathrm{C}} 96.8\right)$; from $\mathrm{H}_{3}-18\left(\delta_{\mathrm{H}} 0.54\right)$ and $\mathrm{H}-15\left(\delta_{\mathrm{H}}\right.$
4.62) to $\mathrm{C}-14$; and from $\mathrm{H}_{2}-16$ and $\mathrm{H}-17$ to $\mathrm{C}-15\left(\delta_{\mathrm{C}} 77.7\right)$ indicated that $\mathrm{C}-7, \mathrm{C}-14$, and $\mathrm{C}-15$ were all oxygenated. The significantly deshielded chemical shift of C-14 and the indices of hydrogen deficiency suggested the presence of an oxetane ring between C-7 and C-14 [8, 11, 12] and a hydroxy group at $\mathrm{C}-15$, similar to that in ciliatasecone $\mathrm{S}$ [8]. Therefore, the 2D structure of $\mathbf{1}$ with a rare oxetane ring was constructed. The ROESY cross-peaks of $\mathrm{H}_{3}-19 / \mathrm{H}_{3}-29, \mathrm{H}_{3}-19 /$ $\mathrm{H}_{3}-30$, and $\mathrm{H}_{3}-30 / \mathrm{H}-7$ (Fig. 2) revealed the $\beta$-orientations of Me-19, Me-29, Me-30, and H-7. The $\alpha$-orientations of $\mathrm{H}-5$, Me-18, and Me-28 were determined by the ROESY cross-peaks of $\mathrm{H}-5 / \mathrm{H}_{3}-28$ and $\mathrm{H}-5 / \mathrm{H}_{3}-18$. The cross-peaks of $\mathrm{H}_{3}-18 / \mathrm{H}-16\left(\delta_{\mathrm{H}} 1.98\right), \mathrm{H}-16\left(\delta_{\mathrm{H}} 1.98\right) / \mathrm{H}-15$, and $\mathrm{H}-16$
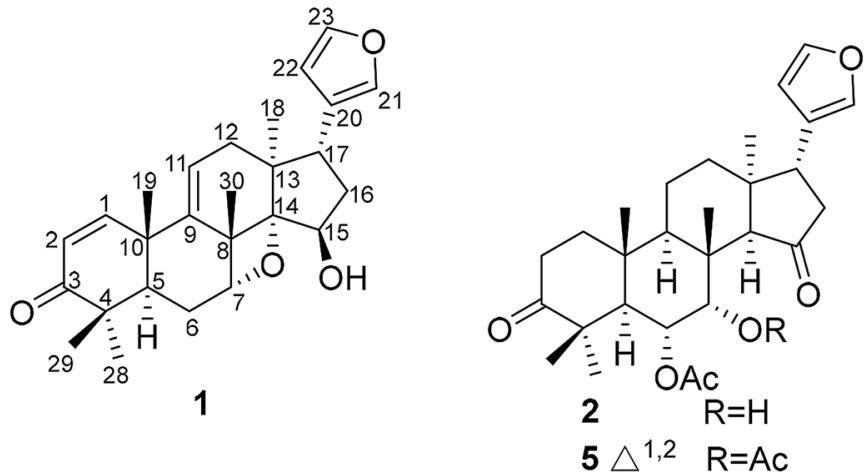

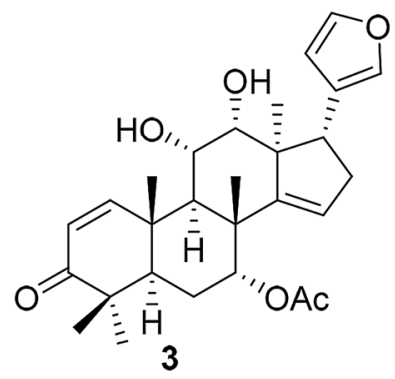

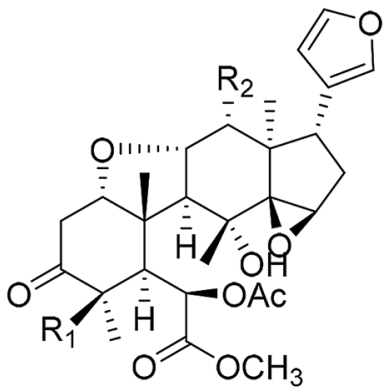

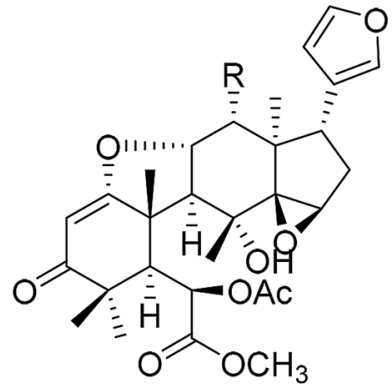

$4 \mathrm{R}_{1}=\mathrm{H} \quad \mathrm{R}_{2}=\mathrm{OH}$

$7 \mathrm{R}=\mathrm{OH}$

$6 \mathrm{R}_{1}=\mathrm{CH}_{3} \mathrm{R}_{2}=\mathrm{H}$

$8 \mathrm{R}=\mathrm{H}$

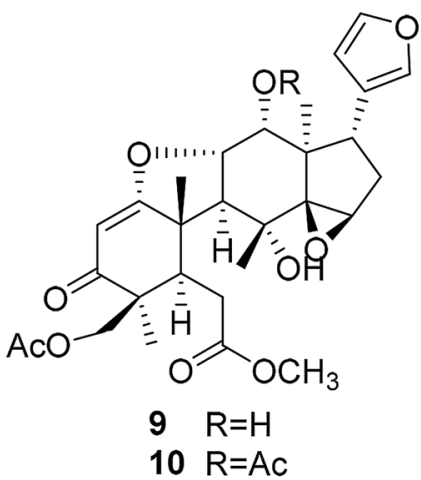

Fig. 1 The structures of compounds $\mathbf{1 - 1 0}$
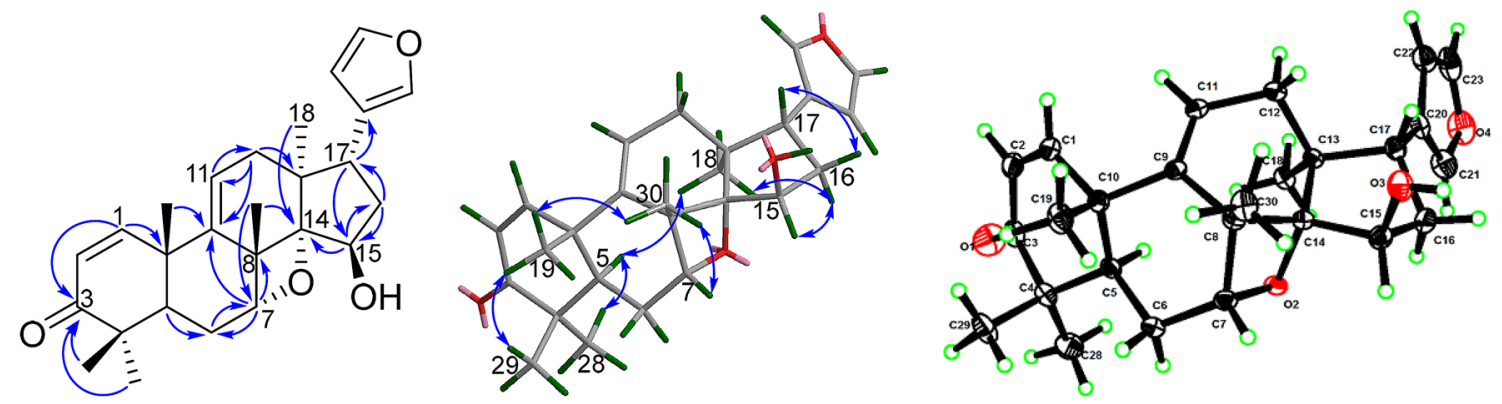

Fig. 2 The key HMBC and ROESY correlations and X-ray crystallographic structure of compound $\mathbf{1}$ 
$\left(\delta_{\mathrm{H}} 1.87\right) / \mathrm{H}-17$ indicated the $\beta$-orientation of $15-\mathrm{OH}$ and the $\alpha$-orientation of furan ring. A single-crystal X-ray crystallographic diffraction experiment with $\mathrm{Cu} \mathrm{K} \alpha$ radiation of 1 (Fig. 2) unambiguously determined the $\alpha$-orientation of the oxetane ring moiety and the absolute configuration as $5 R, 7 R, 8 S, 10 R, 13 S, 14 S, 15 R$, and $17 S$. The structure of compound 1 was thus established as shown.

The molecular formula of toonayunnanae $\mathrm{G}$ (2) was established as $\mathrm{C}_{28} \mathrm{H}_{38} \mathrm{O}_{6}$ based on the HRESIMS ion at $\mathrm{m} / \mathrm{z}$ 493.2551 [M+ Na $]^{+}$(calcd. 493.2561) and its ${ }^{13} \mathrm{C} \mathrm{NMR}$ data. Apart from the signals for an acetoxy substituent, the remaining 26 carbon resonances observed in the 1D NMR spectra indicated that $\mathbf{2}$ might also be a ring-intact limonoid [8-10]. Comparison of its NMR data (Table 1) with those of the known toonaciliatone $F(\mathbf{5})$ [13] revealed that the main differences were the absence of a double bond and an acetoxy group. The chemical shift of C-3 $\left(\delta_{\mathrm{C}} 217.8\right)$ implied the presence of a keto carbonyl rather than an $\alpha, \beta$ unsaturated ketone moiety in ring $\mathrm{A}$, which was confirmed by the HMBC correlations of $\mathrm{H}_{2}-1\left(\delta_{\mathrm{H}} 1.90,1.77\right), \mathrm{H}_{2}-2\left(\delta_{\mathrm{H}}\right.$ $2.76,2.31), \mathrm{H}_{3}-28$, and $\mathrm{H}_{3}-29$ to $\mathrm{C}-3$. The HMBC correlations of $\mathrm{H}-6\left(\delta_{\mathrm{H}} 5.31\right)$ to $\mathrm{C}-5, \mathrm{C}-7\left(\delta_{\mathrm{C}} 72.2\right)$, and an ester carbonyl carbon $\left(\delta_{\mathrm{C}} 169.8\right)$ and of $\mathrm{H}-7\left(\delta_{\mathrm{H}} 3.90\right)$ to C-6 $\left(\delta_{\mathrm{C}}\right.$ 72.1), C-8, C-9, and C-30 (Fig. 3) allowed the assignment of an acetoxyl at C-6 and a hydroxy group at C-7. The relative configuration of $\mathbf{2}$ was deduced to be identical to that of 5 by a ROESY experiment. The ROESY cross-peaks of
$\mathrm{H}_{3}-19 / \mathrm{H}-6, \mathrm{H}_{3}-29 / \mathrm{H}-6, \mathrm{H}_{3}-30 / \mathrm{H}-6, \mathrm{H}-6 / \mathrm{H}-7$, and $\mathrm{H}-7 / \mathrm{H}_{3}-30$ revealed the $\alpha$-orientations of 6-OAc and 7-OH. Therefore, the structure of $\mathbf{2}$ was assigned as depicted.

Toonayunnanae $\mathrm{H}(\mathbf{3})$ gave a molecular formula of $\mathrm{C}_{28} \mathrm{H}_{36} \mathrm{O}_{6}$ as determined from HRESIMS ion at $\mathrm{m} / \mathrm{z}$ 469.2577 $[\mathrm{M}+\mathrm{H}]^{+}$(calcd. 469.2585). The ${ }^{1} \mathrm{H}$ and ${ }^{13} \mathrm{C}$ NMR spectroscopic data showed many similarities to those of the known $6 \alpha$-acetoxyazadirone [13], except for the absence of an acetoxy group and the presence of a hydroxy group. The HMBC correlations of $\mathrm{H}-7\left(\delta_{\mathrm{H}} 5.27\right)$ to C-6, C-8, C-9, C-30, and an ester carbonyl carbon $\left(\delta_{\mathrm{C}} 170.2\right)$ indicated that an acetoxy group was located at $\mathrm{C}-7$. The hydroxy groups at $\mathrm{C}-11$ and $\mathrm{C}-12$ were revealed by the HMBC correlations (Fig. 3) of $\mathrm{H}-11\left(\delta_{\mathrm{H}} 4.30\right)$ to $\mathrm{C}-9$ and $\mathrm{C}-12\left(\delta_{\mathrm{C}} 77.1\right)$ and of H-12 $\left(\delta_{\mathrm{H}} 4.03\right)$ to $\mathrm{C}-11\left(\delta_{\mathrm{C}} 67.8\right)$ and C-13. The ROESY cross-peaks of $\mathrm{H}_{3}-30 / \mathrm{H}-7, \mathrm{H}_{3}-30 / \mathrm{H}-11, \mathrm{H}-11 / \mathrm{H}-12$, and $\mathrm{H}-12 / \mathrm{H}-17$ (Fig. 3) suggested the $\alpha$-orientations of 7-OAc, $11-\mathrm{OH}$, and $12-\mathrm{OH}$. Therefore, the structure of $\mathbf{3}$ was determined as shown.

The clearly diagnostic signals (Table 1) for a $\beta$-substituted furan moiety, five characteristic singlet methyl groups in the 1D NMR spectra, and the correlations of a methoxy group $\left(\delta_{\mathrm{H}} 3.72\right)$ with an ester carbonyl carbon $\left(\delta_{\mathrm{C}} 170.8\right)$ in the HMBC spectrum suggested that toonayunnanae I (4) was likely a B-seco limonoid with a C6-C7-methyl ester appendage $[5,8,14-16]$, similar to toonayunnanin G (6) [15]. Comparison of the 1D NMR

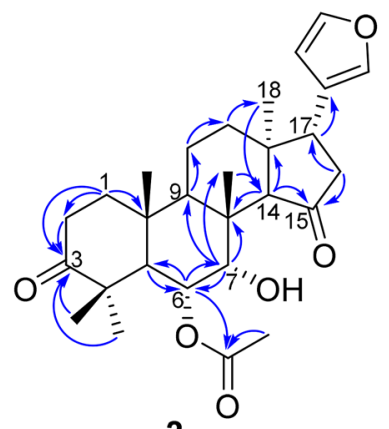

2

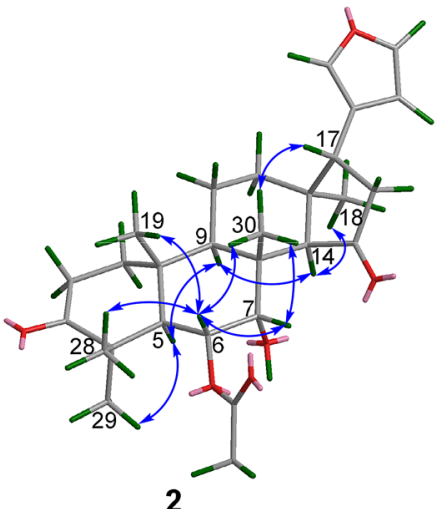

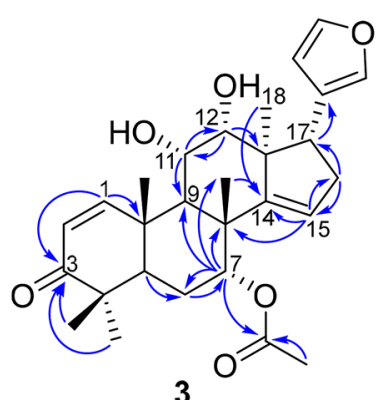

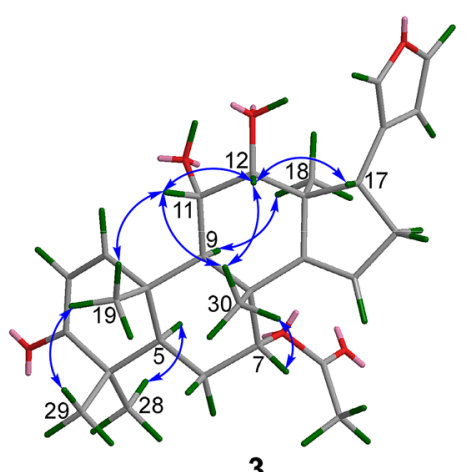

3
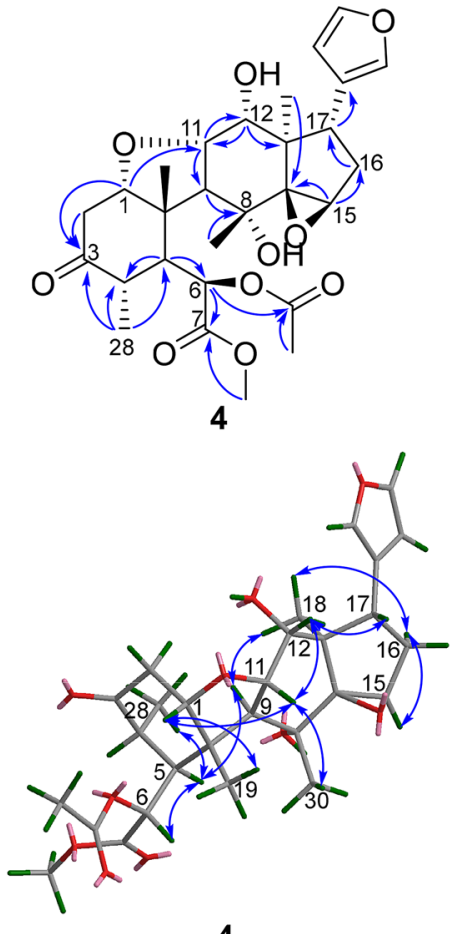

4

Fig. 3 The key HMBC and ROESY correlations of compounds $\mathbf{2}-\mathbf{4}$ 
data (Table 1) of $\mathbf{4}$ with those of $\mathbf{6}$ revealed that the major difference was the presence of a doublet methyl signal $\left(\delta_{\mathrm{H}}\right.$ $1.06,3 \mathrm{H}, \mathrm{d}, J=5.8 \mathrm{~Hz}$ ), which was ascribed to Me-28 at C-4 based on its HMBC correlations (Fig. 3$)$ with C-3 $\left(\delta_{\mathrm{C}}\right.$ $210.1), \mathrm{C}-4\left(\delta_{\mathrm{C}} 41.8\right)$, and C-5 $\left(\delta_{\mathrm{C}} 51.2\right)$. Therefore, 4 possessed a B-seco-29-nor-limonoid skeleton similar to that of ciliatasecone $\mathrm{N}$ [8]. The HMBC correlations of $\mathrm{H}-12\left(\delta_{\mathrm{H}}\right.$ $4.23)$ to $\mathrm{C}-11\left(\delta_{\mathrm{C}} 79.3\right)$ and $\mathrm{C}-13$ indicated that a hydroxy group was located at $\mathrm{C}-12$. The relative configuration of 4 was deduced to be identical to that of 6 by a ROESY experiment. The $\alpha$-orientations of $12-\mathrm{OH}$ and $\mathrm{Me}-28$ in 4 was inferred from the ROESY cross-peaks (Fig. 3) of $\mathrm{H}-11 / \mathrm{H}-12, \mathrm{H}-12 / \mathrm{H}-17$, and $\mathrm{H}_{3}-28 / \mathrm{H}-5$. Accordingly, the structure of $\mathbf{4}$ was elucidated as shown.

By comparing their ${ }^{1} \mathrm{H}$ and ${ }^{13} \mathrm{C}$ NMR spectroscopic data with those reported in literatures, six known compounds were identified as toonaciliatone $F(\mathbf{5})$ [13], toonayunnanin G (6) [15], toonacilianin G (7) [16], toonaciliatin P (8) [17], toonaciliatin C (9) [18], and toonacilianin H (10) [16], respectively.

Additionally, the inhibitory effects on NO generation in LPS-activated RAW 264.7 macrophages of compounds $1-4$ were evaluated at the concentrations of $50 \mu \mathrm{M}$ and below. Compound $\mathbf{1}$ showed NO inhibitory effect with an $\mathrm{IC}_{50} 38.45 \pm 0.41 \mu \mathrm{M}$.

\section{Experimental}

\subsection{General Experimental Procedures}

Optical rotations were measured on a JASCO P-1020 automatic digital polarimeter at room temperature. IR spectra were recorded on a Bruker Tensor 27 spectrometer using $\mathrm{KBr}$ pellets. UV spectra were recorded on a Shimadzu UV-2450 spectrophotometer (Shimadzu, Tokyo, Japan). High-resolution electrospray ionization mass spectrometry (HRESIMS) was obtained on an Agilent 6529B Q-TOF mass instrument using electrospray ionization. The $1 \mathrm{D}$ and $2 \mathrm{D}$ nuclear magnetic resonance (NMR) spectra were obtained on Bruker AVANCE III $500 \mathrm{MHz}$ or Bruker AVIIIHD $600 \mathrm{MHz}$ spectrometers in $\mathrm{CDCl}_{3}$ with TMS as an internal standard. Analytical HPLC was conducted on an Agilent 1260 infinity system equipped with a DAD-UV detector. Preparative HPLC was carried out using a Shimadzu LC-6A system (Shimadzu, Tokyo, Japan) equipped with a Shimpack RP-C ${ }_{18}$ column $(20 \times 200 \mathrm{~mm}$, i.d. $10 \mu \mathrm{m}$, Shimadzu, Tokyo, Japan) with a flow rate of $10.0 \mathrm{~mL} / \mathrm{min}$, detected by a binary channel UV detector. Silica gel (200-300 mesh, Qingdao Haiyang Chemical Co. Ltd., China), MCI (Mitsubishi, Japan), and RP-C 18 silica (40-63 $\mu \mathrm{m}$, FuJi, Japan) were used for column chromatography.

\subsection{Plant Material}

The air-dried bark of Toona ciliata Roem. var. ciliata was collected in Baoshan, Yunnan Province, China, in August 2018. The plant material was identified by professor Mian Zhang of the research Department of Pharmacognosy, China Pharmaceutical University. A voucher specimen (no. 2018TC) was deposited in the Department of Natural Medicinal Chemistry, China Pharmaceutical University.

\subsection{Extraction and Isolation}

The air-dried and powder bark of T. ciliata $(29 \mathrm{~kg})$ was extracted with $95 \%$ EtOH three times $(3 \times 6.5 \mathrm{~L})$ under reflux. The concentrated extract $(3.1 \mathrm{~kg})$ was suspended in $\mathrm{H}_{2} \mathrm{O}$, and then partitioned with petroleum ether (PE) and dichloromethane (DCM), successively. The DCM extract $(100.0 \mathrm{~g})$ was subjected to a silica gel column $(200-300$ mesh) eluted with a PE-EtOAc mixture (100:0 - 100:1 100:2 - 100:3 - 100:5-10:1-5:1, v/v) in a step gradient to obtain eight major fractions $(\mathrm{A}-\mathrm{H})$. Fraction $\mathrm{C}(20.0 \mathrm{~g})$ was loaded onto an ODS column eluted with a mixture of $\mathrm{MeOH}-\mathrm{H}_{2} \mathrm{O}$ from 40 to $70 \%$ to afford four fractions $(\mathrm{C} 1-\mathrm{C} 4)$. Fraction $\mathrm{C} 4(3.3 \mathrm{~g})$ was further applied to an ODS column $\left(30 \%-60 \% \mathrm{ACN}-\mathrm{H}_{2} \mathrm{O}\right)$ to give four subfractions $(\mathrm{C} 4 \mathrm{a}-\mathrm{C} 4 \mathrm{~d})$. Fraction $\mathrm{C} 4 \mathrm{a}(374 \mathrm{mg})$ was separated by preparative $\mathrm{HPLC}$ with $60 \% \mathrm{MeOH}-\mathrm{H}_{2} \mathrm{O}$ to yield $1(4 \mathrm{mg})$ and $2(11 \mathrm{mg})$. Similarly, fraction $\mathrm{C} 4 \mathrm{c}(582 \mathrm{mg})$ afforded $\mathbf{3}$ $(5.3 \mathrm{mg}), \mathbf{5}(14 \mathrm{mg})$, and $\mathbf{8}(10.3 \mathrm{mg})$ by preparative HPLC $\left(50 \% \mathrm{ACN}-\mathrm{H}_{2} \mathrm{O}\right)$. Fraction $\mathrm{D}(15 \mathrm{~g})$ was subjected to an MCI column $\left(50 \%-70 \% \mathrm{MeOH}-\mathrm{H}_{2} \mathrm{O}\right)$ to give three subfractions (D1 - D3). Fraction D2 (5.5 g) was separated by an ODS MPLC $\left(40 \%-60 \% \mathrm{ACN}-\mathrm{H}_{2} \mathrm{O}\right)$ to afford five subfractions (D2a-D2e), and fraction $\mathrm{D} 2 \mathrm{~b}(539 \mathrm{mg}$ ) was purified by preparative $\mathrm{HPLC}$ with $\mathrm{MeOH}-\mathrm{H}_{2} \mathrm{O}\left(60 \% \mathrm{MeOH}-\mathrm{H}_{2} \mathrm{O}\right)$ to give $\mathbf{6}(5.2 \mathrm{mg})$ and $9(14 \mathrm{mg})$. Using the same purification procedures, fraction D3 (3.3 g) was further fractionated by ODS column chromatography $\left(40 \%-60 \% \mathrm{MeOH}-\mathrm{H}_{2} \mathrm{O}\right)$, and the subfraction D3c ( $483 \mathrm{mg}$ ) was purified by preparative HPLC with $45 \% \mathrm{ACN}-\mathrm{H}_{2} \mathrm{O}$ to give $4(2.2 \mathrm{mg}), 7(34.1 \mathrm{mg})$, and 10 (45 mg).

Toonayunnanae $\mathrm{F}(\mathbf{1})$ : colorless crystals $\left(\mathrm{MeOH}-\mathrm{H}_{2} \mathrm{O}\right)$; $[\alpha]_{\mathrm{D}}^{24}+7.6(c 0.1, \mathrm{MeOH}) ; \mathrm{UV}(\mathrm{MeOH}) \lambda_{\max }(\log \varepsilon) 218$ (5.30) nm; IR (KBr) $\nu_{\max } 3553,2986,2931,2859,1669$, $1455,1387,1158,1025 \mathrm{~cm}^{-1} ;{ }^{1} \mathrm{H}$ and ${ }^{13} \mathrm{C}$ NMR data, see Table 1; HRESIMS $m / z 409.2376[\mathrm{M}+\mathrm{H}]^{+}$(calcd. for $\left.\mathrm{C}_{26} \mathrm{H}_{33} \mathrm{O}_{4}, 409.2373\right)$.

Toonayunnanae $\mathrm{G}$ (2): white amorphous powder; $[\alpha]_{\mathrm{D}}^{24}+9.2(c 0.1, \mathrm{MeOH}) ; \mathrm{UV}(\mathrm{MeOH}) \lambda_{\max }(\log \varepsilon) 208$ (3.95) nm; IR (KBr) $\nu_{\text {max }} 3409,2964,1724,1384,1247$, $1028 \mathrm{~cm}^{-1} ;{ }^{1} \mathrm{H}$ and ${ }^{13} \mathrm{C}$ NMR data, see Table 1; HRESIMS $m / z$ 493.2551 [M+Na $]^{+}$(calcd. for $\mathrm{C}_{28} \mathrm{H}_{38} \mathrm{NaO}_{6}, 493.2561$ ). 
Toonayunnanae $\mathrm{H}(\mathbf{3})$ : white amorphous powder; $[\alpha]_{\mathrm{D}}^{24}+7.6(c 0.1, \mathrm{MeOH}) ; \mathrm{UV}(\mathrm{MeOH}) \lambda_{\max }(\log \varepsilon) 208$ (3.55) nm; IR (KBr) $\nu_{\max } 3421,2977,1732,1664,1249$, $1027 \mathrm{~cm}^{-1}$; ${ }^{1} \mathrm{H}$ and ${ }^{13} \mathrm{C}$ NMR data, see Table 1; HRESIMS $m / z 469.2577[\mathrm{M}+\mathrm{H}]^{+}$(calcd. for $\mathrm{C}_{28} \mathrm{H}_{37} \mathrm{O}_{6}, 469.2585$ ).

Toonayunnanae I (4): white amorphous powder; $[\alpha]_{\mathrm{D}}^{24}-30.2(c 0.1, \mathrm{MeOH}) ; \mathrm{UV}(\mathrm{MeOH}) \lambda_{\max }(\log \varepsilon) 208$ (4.02) nm; IR (KBr) $\nu_{\max } 3466,2954,1747,1717,1226$, $1026 \mathrm{~cm}^{-1}$; ${ }^{1} \mathrm{H}$ and ${ }^{13} \mathrm{C}$ NMR data, see Table 1; HRESIMS $m / z \quad 550.2631\left[\mathrm{M}+\mathrm{NH}_{4}\right]^{+}$(calcd. for $\mathrm{C}_{28} \mathrm{H}_{40} \mathrm{NO}_{10}$, $550.2647)$.

\subsection{Anti-inflammatory Activities}

The new compounds $(\mathbf{1}-\mathbf{4})$ were evaluated for their inhibitory effects on NO production in LPS-activated RAW 264.7 macrophages as described in the literature [19]. Briefly, RAW 264.7 cells $\left(6 \times 10^{6}\right.$ cells $\left./ \mathrm{mL}\right)$ were seeded in 96 -well plates and treated with different concentrations of tested compounds for $1 \mathrm{~h}$, and $1.0 \mu \mathrm{g} / \mathrm{mL}$ LPS solution was subsequently added to stimulate the cells for $18 \mathrm{~h}$. NO level was evaluated by measuring the standard of accumulated nitrite in cell supernatants with the reagent of Griess. N-Monomethyl-L-arginine Monoacetate (L-NMMA) was used as a positive control $\left(\mathrm{IC}_{50}=42.38 \pm 0.72 \mu \mathrm{M}\right)$.

Acknowledgements Financial supports for this study were from the National Natural Science Foundation of China (31470416), the National New Drug Innovation Major Project (2018ZX09711-001007), the National Key R\&D Program of China (2018YFC1707105), and the "Double First-Class" University project (CPU2018GY08, China).

\section{Compliance with Ethical Standards}

Conflict of interest The authors declare no conflict of interest.

Open Access This article is licensed under a Creative Commons Attribution 4.0 International License, which permits use, sharing, adaptation, distribution and reproduction in any medium or format, as long as you give appropriate credit to the original author(s) and the source, provide a link to the Creative Commons licence, and indicate if changes were made. The images or other third party material in this article are included in the article's Creative Commons licence, unless indicated otherwise in a credit line to the material. If material is not included in the article's Creative Commons licence and your intended use is not permitted by statutory regulation or exceeds the permitted use, you will need to obtain permission directly from the copyright holder. To view a copy of this licence, visit http://creativecommons.org/licenses/by/4.0/.

\section{References}

1. C.Y. Wu, Index Florae Yunnanensis (I) (The People's Publishing House, Yunnan, 1984), pp. 832-833

2. S.K. Chen, B.Y. Chen, H. Li, In Flora Reipublicae Popularis Sinicae (ZhongguoZhiwu Zhi), 43(3) (Science Press, Beijing, 1997), pp. $239-240$

3. Chinese Materia Medica (Zhonghua Benchao), vol 5 (Shanghai Science and Technology, Shanghai, 1999); pp. 44-45

4. F. Zhang, J.S. Wang, Y.C. Gu, L.Y. Kong, J. Nat. Prod. 75, 538$546(2012)$

5. M.S. Yang, S.M. Hu, L.Y. Kong, J. Luo, Tetrahedron 71, 84728477 (2015)

6. J. Luo, W.S. Huang, S.M. Hu, P.P. Zhang, X.W. Zhou, X.B. Wang, M.H. Yang, J.G. Luo, C. Wang, C. Liu, H.Q. Yao, C. Zhang, H.B. Sun, Y.J. Chen, L.Y. Kong, Org. Chem. Front. 4, 2417-2421 (2017)

7. P.P. Zhang, Z.R. Cui, Y. Li, L. Heng, S.S. Wei, X.B. Wang, M.H. Yang, J. Luo, L.Y. Kong, Org. Biomol. Chem. 17, 555-560 (2019)

8. P.P. Zhang, Z.R. Cui, S.S. Wei, Y. Li, Y. Yin, X.B. Wang, J. Luo, L. Y. Kong, Ind. Crop. Prod. 148, 112275 (2020)

9. B. Zhou, Y. Shen, Y. Wu, Y. Leng, J.M. Yue, J. Nat. Prod. 78, 2116-2122 (2015)

10. Y. Zhang, F.L. An, S.S. Huang, L. Yang, Y.C. Gu, J. Luo, L.Y. Kong, Phytochemistry 136, 108-118 (2017)

11. F.L. An, Y. Yong, J. Luo, L.Y. Kong, Chin. J. Nat. Med. 17, 912 917 (2019)

12. Y. Zhang, J.S. Wang, D.D. Wei, Y.C. Gu, X.B. Wang, L.Y. Kong, J. Nat. Prod. 76, 1191-1195 (2013)

13. S.Y. Jiang, J.Q. Liu, J.J. Xia, Y.X. Yan, M.H. Qiu, Helv. Chim. Acta. 95, 301-307 (2012)

14. X.N. Wang, S. Yin, C.Q. Fan, L.P. Lin, J. Ding, J.M. Yue, Tetrahedron 63, 8234-8241 (2007)

15. J.Q. Liu, C.F. Wang, Y. Li, J.C. Chen, L. Zhou, M.H. Qiu, Phytochemistry 76, 141-149 (2012)

16. J. Liu, S.P. Yang, Z.S. Su, B.D. Lin, Y. Wu, J.M. Yue, Phytochemistry 72, 2189-2196 (2011)

17. F. Zhang, S.G. Liao, C.R. Zhang, X.F. He, W.S. Chen, J.M. Yue, Planta Med. 77, 1617-1622 (2011)

18. S.G. Liao, S.P. Yang, T. Yuan, C.R. Zhang, H.D. Chen, Y. Wu, Y.K. Xu, J.M. Yue, J. Nat. Prod. 70, 1268-1273 (2007)

19. S.S. Wei, J. Chi, M.M. Zhou, R.J. Li, Y.R. Li, J. Luo, L.Y. Kong, Ind. Crop. Prod. 137, 367-376 (2019) 